\title{
TNI-Polri and Jakarta Province Government Cooperation Strategy to Handling Acceleration COVID-19
}

\author{
Wijonarko* Rizerius Eko Hadisancoko Lukman Yudho Prakoso \\ Strategic and Military Campaigns, Universitas Pertahanan, Bogor, Jawa Barat, Indonesia
}

\begin{abstract}
This study discusses the TNI-Polri Cooperation strategy and the Jakarta Provincial Government in accelerating the handling of COVID-19. This study using the theory of Organizational Resources from George R. Terry. The aim is to describe Cooperation regulations, activity methods, the readiness of human resources, and the availability of infrastructure facilities in accelerating the handling of COVID-19. The method used is an observational case studies method with both quantitative and qualitative approaches (mix method) and uses SWOT and AHP for analysis. As a result, the first strategy is to create cooperation policy regulations, the second strategy is to increase public awareness of implementing Health protocols, the third strategy is to create superior human resources, and the fourth strategy is to realize the readiness of facilities and infrastructure.
\end{abstract}

Keywords: cooperation strategy, organizational resources, COVID-19

DOI: $10.7176 /$ RHSS/11-18-06

Publication date:September $30^{\text {th }} 2021$

\section{Introduction}

The world is currently experiencing an outbreak of coronavirus disease (COVID-19), including Indonesia. The World Health Organization (WHO) on March 11, 2020, declared the disease due to COVID-19 a global pandemic. This statement is based on positive cases of COVID-19 in the world increasing thirteen times in 114 countries with a total death of 4,291 people at that time (WHO, 2020).

The increase in the COVID-19 outbreak continues to increase every day. Based on the report of the Committee for Handling COVID-19 and National Economic Recovery as of May 5, 2021, in Indonesia $1,686,373$ people were confirmed positive for COVID-19 with 46,147 people dying. Based on data that DKI Jakarta is the province that contributes the most positive cases of COVID-19 with 411,573 confirmed positive or $24 \%$ nationally with 6,729 deaths (KPCPEN, 2021).

The government realizes that efforts to handle the COVID-19 outbreak require hard work and smart work by not only involving the TNI but also involving other components of the nation and community participation. President Joko Widodo has issued Presidential Instruction (Inpres) No. 6 of 2020. This is a step to ensure that health protocols are implemented in a disciplined and obedient manner by all parties. At the agenda of the TNI and Polri leadership meeting on February 15, 2021, at the State Palace, the President instructed all ranks of the TNI and Polri. First, to continue actively disciplining health protocols, disciplining $3 \mathrm{M}$, and actively supporting 3T. Second, the TNI and Polri support and at the same time strive to ensure that the implementation of restrictions on micro-scale community activities as stated in the Instruction of the Minister of Home Affairs Number 03 of 2021 specifically to Governors and Regents/Mayors can run well. Third, support the implementation of mass vaccination

COVID-19 is a real threat that disrupts national defense. It should be realized that the threat of COVID-19 is a new threat to all countries in the world, including Indonesia. All countries are trying to overcome the threat from this virus by using all the strength of their defense resources. This study focuses on the strategic cooperation between the TNI-Polri and the Provincial Government of DKI Jakarta in dealing with the threat of COVID-19. There are still obstacles in the effort to realize the acceleration of handling COVID-19, especially in DKI Jakarta, so it is necessary to optimize the cooperation between the TNI-Polri and the Provincial Government of DKI Jakarta. It is realized that the cooperation between the TNI and the Police and the Government is in Military Operations Other than War, but in the defense strategy this cooperation is included in the category of development and it is possible that in the future it will be an embryo in military operations. Considering that the threat of COVID-19 still exists and is a real threat to national defense. This research focuses on the DKI Jakarta area regarding the cooperation between the TNI and Polri to accelerate the handling of COVID-19, DKI Jakarta is the capital city of the country where the administration of government is as well as the center of the Indonesian economy. In addition, a significant increase occurred in DKI Jakarta so that it gave birth to many social problems in the community so that optimal cooperation was expected. from the TNI-Polri and the DKI Jakarta provincial government to suppress the spread of COVID-19.

\section{Literature Review}

2.1 National Defence

Based on the National Defense Strategy Book published by the Indonesian Ministry of Defense in 2014, it was 
stated that the national defense strategy was formulated with several basic considerations by the understanding and views of the Indonesian nation in three basic substances in a proportional, balanced and coordinated manner. The national defense strategy shall formulate the objectives, strategic objectives, methods, and means used to realize a strong, effective, and high-defense state defense force and capability. Some of these considerations include that the National Defense Strategy is formulated following the understanding and views of the Indonesian people regarding war and peace. The National Defense Strategy is prepared and implemented to maintain independence from the efforts of any party that threatens the existence of independence. The Indonesian people love peace, but they love independence and sovereignty more. Disputes and conflicts are resolved through peaceful means. For the Indonesian people, war is a last resort and is only carried out if all peace efforts fail.

The national defense strategy is prepared by taking into account the three basic elements that accompany it. First, to shape, which is a strategy that can create and shape a national and international security environment that can guarantee national interests by promoting Jakarta Province stability, reducing and eliminating threats, preventing conflicts, preventing aggression, and other acts of violence. Second, to respond, namely a strategy that can respond to various forms of crises that can create threats and risks to the national interest. Third, to prepare, namely a strategy that can prepare a defense to face an uncertain future by focusing on efforts to build strength, develop concepts and organize defense that utilizes technological advances to protect national interests.

\subsection{Organizational Resource Strategy Theory}

George R. Terry (2012) states that achieving a goal requires the harmonious unification of several available basic resources. George in his book Principles of Management there are six elements of management, namely: 1) Man. Humans make plans and at the same time carry out the process to achieve these goals. Without humans, there will be no planning and work processes in management. Even in an automated world, no organization can develop without human resources. 2) Money. To carry out its activities, management requires costs, both for purchasing and maintaining equipment, purchasing raw materials/materials, paying labor salaries, and so on. Good money management will affect the success or failure of management that is carried out. Therefore, money management must be carried out rationally so that the goals that have been set can be achieved. 3) Materials. Management exists because of activities. In this study, the materials are suggestions and infrastructure. 4) Methods. In management, several methods are needed to determine how a job can be done. A series of procedures and instructions are established taking into account the objectives to be achieved, the facilities available, time, money, and business activities. These methods are defined as standard Operating Standards (SOP), whose role is to increase the use of all resources and production factors so that all work can run effectively and efficiently.

\subsection{Corporation Theory}

The use of cooperation theory as a grand theory in examining the problem of cooperation between the TNI and the Police and the DKI Jakarta Provincial Government can be seen from the perspective of organizational theory and public administration theory, especially in finding models of cooperation between stakeholders and efforts to accelerate the handling of COVID-19. Cooperation according to Abdulsyani (1994) is a form of social interaction. According to Abdulsyani, cooperation is a form of social process, in which certain activities are shown to achieve common goals by helping each other and understanding each other's activities. Cooperation is also defined as an activity carried out jointly by various parties to achieve a common goal. That between group members have their respective roles and complement each other so that integration is formed. A team is several people in a task group who have a common goal. There are several opinions or expert views about teamwork or teamwork. Where the team is several people in a task group who have a common goal. Meanwhile, Schermerhorn (2010) views teamwork as a process carried out by several people together for a common goal, with the opinion "Team building is a sequence of activities to analyze a team and make changes to improve its performance". Teamwork is a process of people working together to achieve a common goal. In teamwork, each member helps each other and works together to complete a work that is a common goal.

Based on the description above, the researcher synthesizes that cooperation is the activity of a person with other members who work together in a group or team by synergizing, working together with mutual understanding and respect, and being responsible for achieving common goals.

\section{Methodology}

\subsection{Research Method}

The method used in this research is a case study method (observational case studies) with a quantitative approach that combines both qualitative and quantitative data input (mix method). Because in this study, the authors move from a case study that produces qualitative data input (human perception) with the help of a questionnaire. However, in the analysis, the qualitative data will be processed into quantitative data using SWOT and AHP 
analysis, where the results of the analysis are then summed up again through the elaboration of the results of the qualitative analysis.

This type of research is descriptive, which is a method that examines certain statuses and objects, certain conditions, systems of thought, or certain events at present (Irawan, 2006).

There are two participant selection techniques (sampling strategies) in this study. The first is random probability sampling, which is taking samples from the population at random by taking into account the number of samples, with the aim that the sample can be generalized to the population. The second is purposeful sampling, in which the sample is selected depending on the purpose of the study without regard to its generalizability (Hayat, 2018).

In this study, the selection of prospective respondents was carried out using a purposeful sampling technique, namely, the sample was selected deliberately to achieve research objectives based on certain criteria set by the researcher. There were 11 resource persons in this study consisting of the TNI, Polri, Jakarta Provincial Government, and BNPB.

Data analysis was carried out using SWOT and AHP, SWOT is an approach to identify various influencing factors and is used to formulate an organization's strategy. This analysis is based on the logic of maximizing Strengths and Opportunities while simultaneously minimizing Weaknesses and Threats. For this reason, SWOT analysis is an important process and is part of strategic management. In an IFAS (Internal Factor Analysis) table, the internal strategic factors consisting of strengths and weaknesses are formulated. While the EFAS (External Factor Analysis) table consists of Opportunities and Threats. Meanwhile, through SFAS (Strategic Factor Analysis Summary) will be obtained an overview of what factors are priorities that are applied in the short, medium, and long periods.

\subsection{Discussion}

Strategy determination is carried out using SWOT analysis, which is an analysis used to identify situations that are categorized as strengths, weaknesses, opportunities, and threats. Every organization needs to analyze the four categories in a SWOT analysis. This is because, in determining the right strategy, it must be determined with careful consideration by analyzing the situation that occurs both internally and externally. Therefore, SWOT is one of the instruments used in analyzing before making decisions in an organization. The strategy analysis used in this paper is AHP SWOT, which is an approach that takes into account the internal and external environment of the organization to determine competitive advantage. In addition, this analysis is also carried out so that it can be applied in determining the priority strategies obtained from the analysis. The method used with AHP (Analytical Hierarchy Process), this method is a method that has been proven effective for dealing with complex decision making, especially in setting priorities and making the best decisions with a series of pairwise comparisons. So far, AHP has only been used to assist decision-makers in converting empirical data into logical, structured, and precise mathematical models. The following are the steps for applying the theory of EFAS, IFAS, and SFAS through the AHP approach. IFAS (Internal Factor Analysis). The results of the IFAS calculation can be seen in the following table:

Table 1. IFAS Calculating Results

\begin{tabular}{|c|l|c|c|c|}
\hline $\mathrm{N}$ & \multicolumn{1}{|c|}{ Internal Factor } & Weight & Rating & Score \\
\cline { 2 - 4 } $\mathrm{O}$ & Strengths & & & \\
\hline 1 & TNI-Polri Cooperation Policy and Jakarta Government & 0,20 & 5 & 1,02 \\
\hline 2 & The Strength of Human Resources to deal with the COVID-19 pandemic & 0,05 & 3 & 0,16 \\
\hline 3 & Health Protocol Discipline Joint Operation Program & 0,07 & 5 & 0,33 \\
\hline 4 & "Kampung Tanguh" Program & 0,16 & 3 & 0,48 \\
\hline 5 & Software that helps Testing Tracing, Treatment (3T) & 0,02 & 4 & 0,07 \\
\hline & Weakness & 0,19 & 2,5 & 0,48 \\
\hline 1 & $\begin{array}{l}\text { No regulation defines the involvement of the TNI-Polri in the mechanism } \\
\text { for accelerating the handling of COVID-19 }\end{array}$ & 0,04 & 2 & 0,08 \\
\hline 2 & The limited number and ability of personnel & 0,05 & 2,5 & 0,14 \\
\hline 3 & $\begin{array}{l}\text { The existence of sectoral egos within the TNI-Polri and Jakarta Province } \\
\text { Governments }\end{array}$ & 0,14 & 2 & 0,29 \\
\hline 4 & $\begin{array}{l}\text { Limited PPE and hospital facilities for TNI-Polri and Jakarta Province } \\
\text { governments }\end{array}$ & 0,07 & 2 & 0,14 \\
\hline 5 & Low health protocol disciplinary enforcement activities & $\mathbf{1 , 0 0}$ & $\mathbf{3 , 1 8}$ \\
\hline & \multicolumn{1}{|c|}{ TOTAL }
\end{tabular}

After knowing the internal factors, then determine the external factors EFAS (External Factor Analysis).

The results of the EFAS calculation can be seen in the following table: 
Table 2. EFAS Calculating Results

\begin{tabular}{|c|c|c|c|c|}
\hline \multirow[t]{2}{*}{ NC } & External Factor & \multirow[t]{2}{*}{ Weight } & \multirow[t]{2}{*}{ Rating } & \multirow[t]{2}{*}{ Score } \\
\hline & Opportunities & & & \\
\hline 1 & $\begin{array}{l}\text { Komitemen Presiden Republik Indonesia dalam mensinergikan TNI-Polri } \\
\text { dalam mendukung kebijakan pemerintah }\end{array}$ & 0,11 & 5 & 0,53 \\
\hline 2 & Kesadaran global dalam percepatan penanganan COVID-19 & 0,05 & 3 & 0,14 \\
\hline 3 & Dukungan media dalam mensosialisasikan disiplin protokol kesehatan & 0,12 & 4 & 0,49 \\
\hline 4 & Dukungan negara lain dalam pengadaan vaksin & 0,19 & 5 & 0,97 \\
\hline 5 & $\begin{array}{l}\text { Kekayaan Sumber Daya Alam yang bisa digunakan untuk meningkatkan daya } \\
\text { tahan tubuh }\end{array}$ & 0,03 & 2 & 0,06 \\
\hline & Threats & & & \\
\hline 1 & $\begin{array}{l}\text { Rendahnya kesadaran dan disiplin masyarakat untuk menjalankan kebijakan } \\
\text { 3M dan 3T }\end{array}$ & 0,18 & 2,5 & 0,45 \\
\hline 2 & Terbatasnya produk-produk peralatan medis produksi dalam negeri & 0,07 & 2 & 0,15 \\
\hline 3 & Peningkatan kriminalitas dan tindak kejahatan lain selama pandemi & 0,06 & 2,5 & 0,16 \\
\hline 4 & Jumlah Vaksin dari luar negeri yang belum memadai & 0,16 & 2,5 & 0,40 \\
\hline 5 & Menurunnya kepercayaan masyarakat terhadap pemerintah & 0,03 & 2 & 0,05 \\
\hline & TOTAL & 1,00 & & 3,39 \\
\hline
\end{tabular}

Based on the data above, it is found that Strength (S) and Weakness (W) with a weighted score (3.18). While Opportunities (O) and Threats (T) have a weighted score (3.39). Referring to the SWOT quadrant of Pearce \& Robinson, the organization's position is in quadrant I (Figure 1) position with the strategy applied is aggressive. The aggressive strategy is logical, analytical thinking and conceptualization of priority matters to be used as a reference in determining strategies and efforts that must be carried out in an integrated manner so that activities are carried out by the goals, objectives, and results (outputs) that must be achieved based on the policies that have been implemented that previously set.

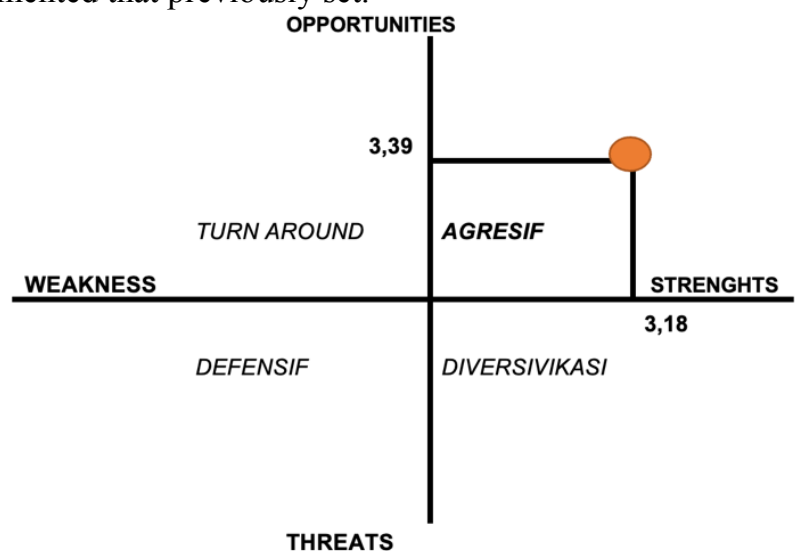

Figure 1. IFAS and EFAS Quadrants Score

To maintain the safety of the nation and state by accelerating the handling of the COVID-19 pandemic appropriately and efficiently through the cooperation of the TNI-Polri and the Jakarta Province Government based on established policies, it is necessary to formulate a strategy.

First strategy is to create clear policy regulations for the TNI-Polri and Jakarta Government cooperation in accelerating the handling of Covid-19, through the submission of laws and regulations that explicitly regulate the role and involvement of the TNI-Polri and Jakarta Governments in accelerating the handling of COVID-19, issuance of Government Regulation in lieu of Law (Perpu) which regulates the role and involvement of the TNIPolri and Jakarta Province Governments in accelerating the handling of COVID-19, preparation and issuance of software that regulates the duties and responsibilities of the TNI-Polri and Jakarta Province Governments in accelerating the handling of COVID -19, and strengthening the cooperation between the TNI-Polri and the Jakarta Province Government in order to increase the participation of their respective agencies in accelerating the handling of COVID-19, with the method of determining, reviewing, coordinating, instructing, revising, ratifying, socializing and cooperating, using legislation in the form of Laws. Laws, Presidential Decrees, Ministerial Regulations, Pera the order of the TNI Commander, the National Police Chief Regulation and a warrant, to achieve the goal of realizing the TNI-Polri and Jakarta Province Government cooperation policies to accelerate the handling of Covid-19 to maintain the safety of the Nation and the State.

The second strategy is to realize increased public awareness in implementing health protocols, through the implementation of social campaigns on the importance of health protocols and restrictions on mobility to suppress the spread of COVID-19, expansion, and development of Tangguh Nusantara Village to accelerate the 
handling of COVID-19, media management to prevent and overcome various provocative content in the form of hoaxes and hate speech about COVID-19, and increasing public education activities to suppress the spread of COVID-19, issuance of regulations, education, socialization, and law enforcement, using the means of Presidential Regulations, Ministerial Regulations, Governor Regulation, Regent/Mayor Regulation, and other related provisions, to achieve the goal of realizing increased public awareness in implementing health protocols to accelerate the handling of COVID-19 to maintain the safety of the nation and state.

The third strategy is to realize the preparation of superior human resources in accelerating the handling of COVID-19, through increasing personnel knowledge about COVID-19 carried out periodically and intensively by involving health and epidemiologist experts, providing information systems or applications that are accurate, reliable, and precise. time, and Preparation of Human Resources in overcoming limited personnel to accelerate the handling of COVID-19, with methods of recruitment, education, education, training, and socialization using educational institutions in the ranks of the TNI-Polri, Educational Institutions of Ministries/Agencies, and other educational institutions involved to achieve the goal of realizing the preparation of superior human resources in accelerating the handling of COVID-19 to accelerate the handling of COVID-19 to maintain the safety of the nation and state.

The fourth strategy is to realize the preparation of facilities and infrastructure to support the acceleration of handling COVID-19, through the use of domestic medical equipment products to support the acceleration of handling COVID-19, support and oversee the vaccine program in the context of accelerating the handling of COVID-19, maximizing hospital facilities and public infrastructure facilities in meeting the handling of exposure to COVID-19 methods of procurement, maintenance, development and utilization using the facilities of all health facilities and other facilities that can be utilized to achieve the goal of realizing facilities and infrastructure to support the acceleration of handling the COVID-19 pandemic to accelerate the handling of COVID -19 to maintain the safety of the nation and state.

\section{Conclusion}

There is no policy regulation on cooperation between TNI-Polri institutions and the Jakarta Province Government in accelerating the handling of COVID-19, there are still conflicts in the community regarding the involvement of the TNI in handling COVID-19 and it is necessary to clarify the main tasks and functions of the TNI-Polri and Jakarta Province Governments in accelerating the handling. COVID-19 pandemic. The solution is to create clear policy regulations for the TNI-Polri and Jakarta Province Government cooperation in accelerating the handling of COVID-19, through the submission of laws and regulations that explicitly regulate the role and involvement of the TNI-Polri and Jakarta Province Governments in accelerating the handling of COVID-19, publishing Government Regulation instead of Law (Perpu) which regulates the role and involvement of the TNIPolri and Jakarta Province Governments in accelerating the handling of COVID-19, compiling and publishing software that regulates the duties and responsibilities of the TNI-Polri and Jakarta Province Governments in accelerating the handling of COVID-19 19, and strengthening the cooperation between the TNI-Polri and the Jakarta Province Government to increase the participation of their respective agencies in accelerating the handling of COVID-19.

Low public awareness of the importance of Health protocols and restrictions on COVID-19 mobility is an important key in accelerating the handling of the COVID-19 pandemic. The solution is to increase public awareness in implementing health protocols through the implementation of social campaigns on the importance of health protocols and mobility restrictions to suppress the spread of COVID-19, expansion, and development of Tangguh Nusantara Village to accelerate the handling of COVID-19, media management to prevent and deal with various provocative content. in the form of hoaxes and hate speech about COVID-19, as well as increasing public education activities to suppress the spread of COVID-19.

Limited human resources both in quality and quantity. Lack of personnel knowledgeable about the development of COVID-19 and the use of applications in tracing efforts; and the limited number of personnel to accelerate the handling of COVID-19 considering that personnel also have to maintain public security and order. The solution is to realize the preparation of superior human resources in accelerating the handling of COVID-19, through increasing personnel knowledge about COVID-19 which is carried out periodically and intensively to accelerate the handling of COVID-19 and Preparation of Human Resources in overcoming the limited personnel to accelerate the handling of COVID -19 .

The limited health facilities and infrastructure of the TNI-Polri and Jakarta Province Government units to accelerate the handling of the COVID-19 pandemic, such as the need for Personal Protective Equipment (PPE), the availability of vaccines, and hospital facilities. The solution is with. realizing the preparation of supporting facilities and infrastructure to accelerate the handling of COVID-19, through the use of domestic medical equipment products in supporting the acceleration of handling COVID-19, supporting and overseeing the vaccine program in the context of accelerating the suppression of COVID-19, maximizing hospital facilities, and public infrastructure in meeting the handling of exposure to COVID-19. 


\section{References}

Abdulsyani. (1994). Sosiologi Skematika, Teori, dan Terapan. Jakarta: Bumi Aksara.

Irawan, P. (2006). Penelitian Kualitatif \& Kuantitatif untuk Ilmu-Ilmu Sosial, Jakarta: Departemen Ilmu Administrasi FISIP-UI.

Hayat, AM. (2018). Adaptasi Komunikasi Guru Asing Menghadapi Perbedaan Budaya Di Sekolah Internasional. Jurnal Widya Komunika Vo. 8 No. 1. Halaman 76-86.

KPCPEN. (2021). Peta Sebaran COVID-19. https://covid19.go.id/peta-sebaran-covid19.

Rangkuti, F. (2015). Analisis SWOT: Teknik Membedah Kasus Bisnis. PT Gramedia Pusaka Utama: Jakarta.

Terry, GR. (2012). Prinsip-Prinsip Manajemen. D.F.M. Jakarta: PT Bumi Aksara.

WHO. (2020). Retrieved from WHO Director-General's opening remarks at the media briefing on COVID-19 11 Maret 2020: https://www.who.int/dg/speeches/detail/who-director-general-s-opening-remarks-at-themedia- . 